\title{
Anthranoyl-substituted Norditerpene Alkaloids from Aconitum vulparia Rchb. and Their Cytotoxic Activities
}

\author{
Dezső Csupor $^{\mathrm{a}}$, Peter Forgo ${ }^{\mathrm{b}}$, István Zupkóc ${ }^{\mathrm{c}}$, Pál Szabó ${ }^{\mathrm{d}}$, and Judit Hohmann ${ }^{\mathrm{a}}$ \\ a Department of Pharmacognosy, University of Szeged, H-6720 Szeged, Hungary \\ b Department of Organic Chemistry, University of Szeged, H-6720 Szeged, Hungary \\ c Department of Pharmacodynamics and Biopharmacy, University of Szeged, H-6720 Szeged, \\ Hungary \\ ${ }^{d}$ Institute of Chemistry, Chemical Research Centre, Hungarian Academy of Sciences, \\ H-1525 Budapest, Hungary
}

Reprint requests to Prof. J. Hohmann. Fax: +36-62-545-704.

E-mail: hohmann@pharma.szote.u-szeged.hu

\section{Z. Naturforsch. 2007, 62b, $135-141$; received August 8, 2006}

\begin{abstract}
Extensive chromatographic purification of the alkaloid fraction of Aconitum vulparia Rchb. led to the isolation of a new norditerpene alkaloid, vulparine (1), besides the known compounds septentriodine (2), finetiadine (3), anthranoyllycoctonine (4), $N$-methyl- $N$-deethyllycoctonine (5) and delectinine (6). The structure of the new compound was determined by means of HRMS, 1D and 2D NMR spectroscopy. Detailed NMR studies, including ${ }^{1} \mathrm{H}_{-}{ }^{1} \mathrm{H}$ COSY, NOESY, HSQC and HMBC experiments, resulted in complete and unambiguous ${ }^{1} \mathrm{H}$ chemical shift assignments for $\mathbf{2}$ and $\mathbf{6}$, and revision of some ${ }^{13} \mathrm{C}$ NMR data. Compounds $1-4$ were evaluated for their cytotoxic activities, and 1, 3 and $\mathbf{4}$ were found to exhibit marginal cell growth inhibitory activity against breast adenocarcinoma (MCF-7) and cervix adenocarcinoma (HeLa) cells.
\end{abstract}

Key words: Aconitum vulparia, Norditerpene Alkaloid, Cytotoxicity

\section{Introduction}

Aconitum, Delphinium and Consolida species are known to produce various hydroxy-, alkoxy- and estersubstituted diterpene and norditerpene alkaloids. Many $\mathrm{C}_{19}$ lycoctonine-type alkaloids exhibit high toxicity and a broad spectrum of pharmacological activities, including antinociceptive, anti-inflammatory, local anaesthetic, antioxidant and tyrosinase inhibitory activities [1-3]. Moreover, norditerpene alkaloids with an $N$-substituted anthranylate ester side-chain, e.g. methyllycaconitine (MLA), display extremely great affinity and high selectivity for the $\alpha 7$ nicotinic acetylcholine receptor (nAChR) subtype, and are therefore prime lead compounds for the design and synthesis of new drugs for the therapy of Alzheimer's disease, epilepsy and schizophrenia $[4,5]$. In recent years it was demonstrated that norditerpene alkaloids can act on biological targets other than neuroreceptors: they exhibit cytotoxic effect against insect Sf9 and different human tumour cell lines with strong molecular selectivity [6-8]. In a previous paper, we reported the isolation of a new norditerpene alkaloid, acovulparine, from A. vulparia, together with lycoctonine and delcosine [9]. On completion of our studies on this plant, we now describe the isolation and structure elucidation of a further new norditerpene alkaloid, vulparine (1), and five known compounds: septentriodine (2), finetiadine (3), anthranoyllycoctonine (4), $N$-methyl- $N$-deethyllycoctonine (5) and delectinine (6). The complete and unambiguous ${ }^{1} \mathrm{H}$ and ${ }^{13} \mathrm{C}$ NMR signal assignments of compounds $\mathbf{2}$ and $\mathbf{6}$, and the results of the cytotoxic assay of vulparine (1), septentriodine (2), finetiadine (3), anthranoyllycoctonine (4) on breast adenocarcinoma (MCF-7) and cervix adenocarcinoma (HeLa) cells are also reported in this paper.

\section{Results and Discussion}

Compound 1 was isolated as an amorphous solid. The molecular formula $\mathrm{C}_{36} \mathrm{H}_{50} \mathrm{~N}_{2} \mathrm{O}_{11}$ was derived from the HR mass spectrum $\left([\mathrm{M}+\mathrm{H}]^{+} m / z=687.3437\right.$, $[\mathrm{M}+\mathrm{H}]^{+}$calcd. 687.3493) combined with the NMR data. The ${ }^{1} \mathrm{H}$ NMR spectrum of 1 indicated the presence of aromatic protons $\left(\delta_{\mathrm{H}}=7.11 \mathrm{t}, 7.55 \mathrm{t}, 7.96 \mathrm{~d}\right.$, $8.70 \mathrm{~d})$, which were attributed to an anthranoyl group, 


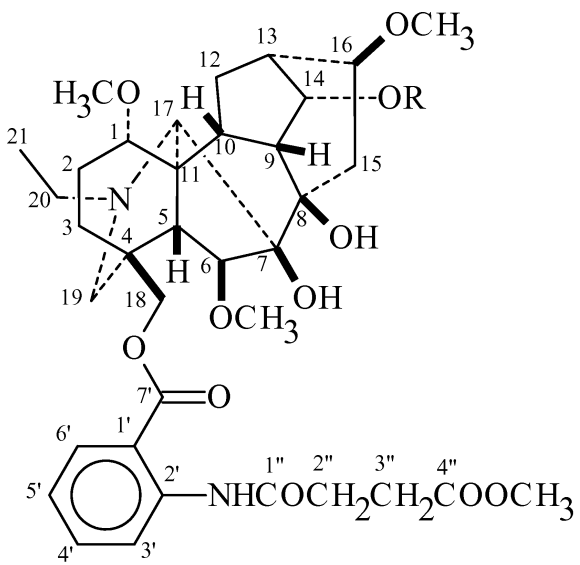

$\mathrm{R}$

$1 \mathrm{H}$

$2 \mathrm{CH}_{3}$

$3 \mathrm{COCH}_{3}$

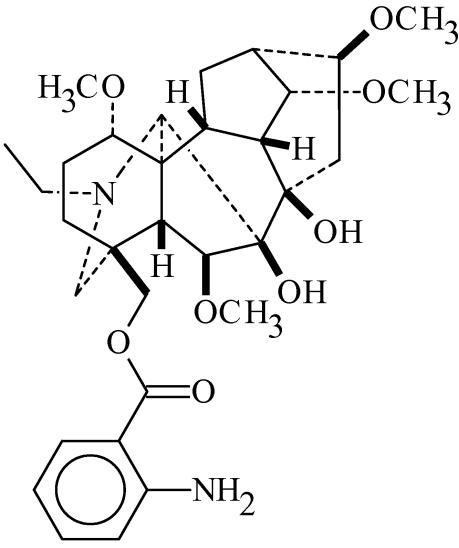

4

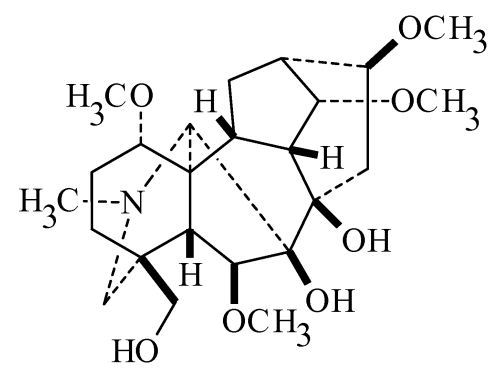

5

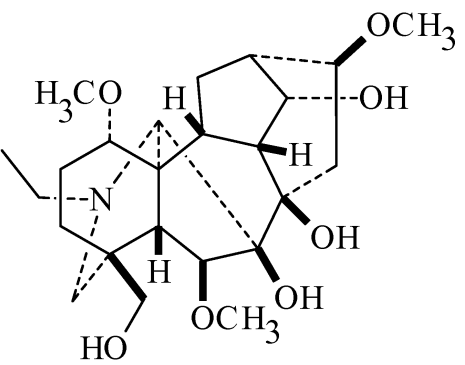

6

Scheme 1.

found in many Aconitum alkaloids. Additionally, signals of the protons of four methoxy groups $\left(\delta_{\mathrm{H}}=\right.$ $3.26 \mathrm{~s}, 3.36 \mathrm{~s}, 3.39 \mathrm{~s}, 3.70 \mathrm{~s})$ and one $N$-ethyl substituent $\left(\delta_{\mathrm{H}}=1.07 \mathrm{t}, 2.85 \mathrm{dq}, 2.97 \mathrm{dq}\right)$ were present. In the JMOD spectrum $(J$-modulated spin-echo experiment), the signals of 36 carbons could be identified (Table 1). Apart from the signals of the anthranoyl group $\left(\delta_{\mathrm{C}}=114.7,120.7,122.6,130.3,134.9,141.7\right.$, $168.1)$, four methoxy groups $\left(\delta_{\mathrm{C}}=51.8,55.9,56.6\right.$, $58.4)$ and an $N$-ethyl substituent $\left(\delta_{\mathrm{C}}=14.1,51.1\right), 19$ signals could be identified, assignable to a norditerpene core. The remaining 4 signals $\left(\delta_{\mathrm{C}}=29.0,32.8\right.$, $170.2,172.0)$ revealed the presence of a succinoyl chain $\left(-\mathrm{COCH}_{2} \mathrm{CH}_{2} \mathrm{CO}-\right)$ in the molecule. The HSQC experiments allowed the assignment of protons and protonated carbons. Interpretation of the proton-proton connectivities in the ${ }^{1} \mathrm{H}-{ }^{1} \mathrm{H}$ COSY spectrum led to the identification of three structural fragments [-CH$\mathrm{CH}_{2}-\mathrm{CH}_{2}-$ (fragment A), $-\mathrm{CH}-\mathrm{CH}-$ (fragment $\mathrm{B}$ ) and $-\mathrm{CH}-\mathrm{CH}-\mathrm{CH}(\mathrm{OR})-\mathrm{CH}\left(\mathrm{CH}(\mathrm{OR})-\mathrm{CH}_{2}\right)-\mathrm{CH}_{2}-$ (fragment $\mathrm{C})$ ], two isolated methylenes $\left(\delta_{\mathrm{H}}=2.53 \mathrm{~d}, 2.78 \mathrm{~m}\right.$ and $4.15 \mathrm{~d}, 4.20 \mathrm{~d}$, respectively), one isolated methine $\left(\delta_{\mathrm{H}}=3.28 \mathrm{~s}\right)$, and one ethyl group (Fig. 1).

The long-range HMBC correlations confirmed, that structural fragments A-C, two methylene groups (C-18, C-19) and one methine group (C-17) together with the quaternary carbons C-4, C-7, C-8, C-11 build up the norditerpene skeleton. Important two- and three- 


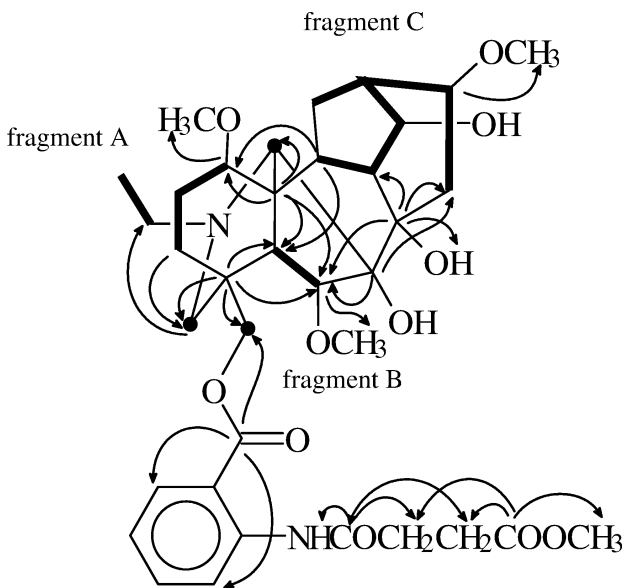

Fig. 1. Selected ${ }^{1} \mathrm{H}^{-1} \mathrm{H} \operatorname{COSY}(\longrightarrow)$ and $\operatorname{HMBC}(\mathrm{C} \rightarrow \mathrm{H})$ correlations for $\mathbf{1}$.

bond correlations were observed between the quaternary carbon at $\delta_{\mathrm{C}}=48.4(\mathrm{C}-11)$ and the protons at $\delta_{\mathrm{H}}=$ $3.02(\mathrm{H}-1), 1.80(\mathrm{H}-5), 3.89(\mathrm{H}-6)$ and $3.28(\mathrm{C}-17)$, and between the carbon at $\delta_{\mathrm{C}}=37.9(\mathrm{C}-4)$ and the protons at $\delta_{\mathrm{H}}=1.80(\mathrm{H}-5), 3.89(\mathrm{H}-6), 4.20(\mathrm{H}-18 \mathrm{a}), 4.15$ (H-18b) and 2.78 (H-19a), indicating that fragment A and the quaternary carbons $\mathrm{C}-4$ and $\mathrm{C}-11$ form a sixmembered ring. The correlations of the carbon at $\delta_{\mathrm{C}}=$ $89.3(\mathrm{C}-7)$ with the protons at $\delta_{\mathrm{H}}=3.89(\mathrm{H}-6)$ and $2.50(\mathrm{H}-15 \beta)$, of the carbon at $\delta_{\mathrm{C}}=76.3(\mathrm{C}-8)$ with the protons at $\delta_{\mathrm{H}}=3.89(\mathrm{H}-6), 3.13(\mathrm{H}-9)$ and 2.50 $(\mathrm{H}-15 \beta)$ and of the carbon at $\delta_{\mathrm{C}}=46.1(\mathrm{C}-10)$ with the protons at $\delta_{\mathrm{H}}=3.02(\mathrm{H}-1)$ and $1.80(\mathrm{H}-5)$ proved the linkage of structural parts $\mathrm{C}$ and $\mathrm{B}$ with the sixmembered ring, as depicted in Fig. 1. The HMBC spectrum also provided information on the locations of the four methoxy groups, one anthranoyl group, and one hydroxy group. The long-range correlations of the carbons of the norditerpene core at $\delta_{\mathrm{C}}=76.3(\mathrm{C}-8), 81.8$ (C-16), $84.8(\mathrm{C}-1)$ and $90.6(\mathrm{C}-6)$ with the protons at $\delta_{\mathrm{H}}=3.53(1 \mathrm{H}), 3.36,3.26$ and $3.39($ each $3 \mathrm{H})$ revealed the positions of one hydroxy group at $\mathrm{C}-8$ and three methoxy groups at C-16, C-1 and C-6. The correlation of the carbon at $\delta_{\mathrm{C}}=52.6(\mathrm{C}-19)$ with the proton at $\delta_{\mathrm{H}}=2.97(\mathrm{H}-20 \mathrm{a})$ confirmed the position of the $N$ ethyl group. The position of the anthranoyl group at C-18 was determined via the correlations of the carbonyl carbon at $\delta_{\mathrm{C}}=168.1\left(\mathrm{C}-7^{\prime}\right)$ with the protons at $\delta_{\mathrm{H}}=8.70\left(\mathrm{H}-3^{\prime}\right), 7.96\left(\mathrm{H}^{-6}{ }^{\prime}\right), 4.20(\mathrm{H}-18 \mathrm{a})$ and 4.15 (H-18b). In view of the molecular formula of $\mathbf{1}$ and the ${ }^{13} \mathrm{C}$ chemical shifts of C-7 $\left(\delta_{\mathrm{C}}=89.3\right)$ and C-14 $\left(\delta_{\mathrm{C}}=\right.$ $75.3)$, the presence of further two hydroxy groups was concluded, situated at $\mathrm{C}-7$ and $\mathrm{C}-14$. Moreover, the presence of a $-\mathrm{CO}-\mathrm{CH}_{2}-\mathrm{CH}_{2}-\mathrm{COOCH}_{3}$ side-chain, attached to the amino group of the anthranoyl moiety, was demonstrated by several correlations of carbonyl carbons $\left[\delta_{\mathrm{C}}=170.2\left(\mathrm{C}-1^{\prime \prime}\right)\right.$ and $\left.172.0\left(\mathrm{C}-4^{\prime \prime}\right)\right]$ with methylene protons $\left[\delta_{\mathrm{H}}=2.76\left(4 \mathrm{H}, \mathrm{H}-2^{\prime \prime}, \mathrm{H}-3^{\prime \prime}\right)\right]$, a methoxy group $\left(\delta_{\mathrm{H}}=3.70\right)$ and the $\mathrm{NH}$ group $\left(\delta_{\mathrm{H}}=\right.$ 11.07) (Table 1).

The relative stereochemistry of $\mathbf{1}$ was studied by means of a NOESY experiment and evaluation of the coupling constants. As starting point, the stereochemistry of H-5 was considered to be $\beta$, as characteristic for norditerpene alkaloids [10]. The coupling constant $(J=0 \mathrm{~Hz})$ between H-5 and H-6 demonstrated the $\alpha$ position of H-6 [9]. The Overhauser effect between H-5 and $\mathrm{H}-18$ was indicative of the $\beta$ position of H-18. Consequently, H-19 must be in the $\alpha$ position, and the $N$-containing bridge between $\mathrm{C}-19$ and $\mathrm{C}-17$ is below the plane of the six-membered ring. The NOESY correlation between $\mathrm{H}-17$ and $\mathrm{H}-16$ pointed to an $\alpha$-oriented $\mathrm{H}-16$. The stereochemistry of $\mathrm{C}-1$ was determined from the NOESY cross-peaks between $\mathrm{H}-19$ and $\mathrm{H}-2 \alpha$ and between $\mathrm{H}-2 \beta$ and $\mathrm{H}-1$. The $\beta$ orientation of $\mathrm{H}-1$ was corroborated by comparison of its coupling constant $(J=10.3,7.1 \mathrm{~Hz})$ with those published for this type of norditerpene alkaloids [11,12]. Further important NOEs were detected between H-9 and $\mathrm{H}-14$, between $\mathrm{H}-9$ and $8-\mathrm{OH}$, and between $\mathrm{H}-13$ and $\mathrm{H}-14$, which confirmed the same stereostructure of compound $\mathbf{1}$ as that of the co-occurring lycoctonine, with $\beta$-oriented H-9, H-13, H-14 and 8-OH [9]. Additionally, some NOESY correlations were suitable for the steric differentiation of methylene protons (C-2, C-3 and C-15). Such correlations were observed between $\mathrm{H}-19 \mathrm{a}$ and $\mathrm{H}-2 \alpha ; \mathrm{H}-2 \beta$ and $\mathrm{H}-3 \beta ; \mathrm{H}-16$ and $\mathrm{H}-15 \alpha$; and $\mathrm{H}-17$ and $\mathrm{H}-15 \alpha$. All of the above evidence confirmed the structure $\mathbf{1}$ for this compound, named vulparine.

Compound $\mathbf{2}$ was identified as septentriodine (= cashmiradelphine) by comparison of its physical and spectral data with those reported in the literature $[13,14]$. This compound was previously isolated from Aconitum septentrionale [13] and from A. barbatum var. puberulum [15] under the name septentriodine, and from Delphinium cashmirianum under the name cashmiradelphine. In these earlier publications, the structure was presented with a $\beta$-oriented 1-OMe group. In a later publication by the Pelletier group, this substituent was placed in the $\alpha$ position [16]. Our NOESY experiment provided unequivocal evidence for a $1 \alpha$-OMe group, since Overhauser effects were 


\begin{tabular}{|c|c|c|c|c|}
\hline Atom & ${ }^{1} \mathrm{H}$ & ${ }^{13} \mathrm{C}$ & $\operatorname{HMBC}(\mathrm{C} \rightarrow \mathrm{H})$ & $\overline{\operatorname{COSY}(\mathrm{H} \mathrm{No})}$ \\
\hline$\overline{1}$ & $3.02 \mathrm{dd}(7.1,10.3)$ & 84.8 & 1-OMe & $2 \alpha, 2 \beta$ \\
\hline $2 \alpha$ & $2.15 \mathrm{~m}$ & 25.4 & - & $1,2 \beta, 3 \alpha, 3 \beta$ \\
\hline $2 \beta$ & $2.05 \mathrm{~m}$ & & & $1,2 \alpha, 3 \beta$ \\
\hline $3 \alpha$ & $1.82 \mathrm{~m}$ & 32.3 & $18 \mathrm{a}, 18 \mathrm{~b}, 19 \mathrm{~b}$ & $2 \alpha, 3 \beta$ \\
\hline $3 \beta$ & $1.50 \mathrm{~m}$ & & & $2 \alpha, 2 \beta, 3 \alpha$ \\
\hline 4 & - & 37.9 & $5,6,18 \mathrm{a}, 18 \mathrm{~b}, 19 \mathrm{a}$ & - \\
\hline 5 & $1.80 \mathrm{~s}$ & 50.7 & $17,18 \mathrm{a}, 19 \mathrm{a}$ & $6,17 *$ \\
\hline 6 & $3.89 \mathrm{~s}$ & 90.6 & $5,17,6-\mathrm{OMe}$ & 5 \\
\hline 7 & - & 89.3 & $6,15 \alpha$ & - \\
\hline 8 & - & 76.3 & $6,8-\mathrm{OH}, 9,15 \beta$ & - \\
\hline 9 & $3.13 \mathrm{brs}$ & 45.2 & - & 10,14 \\
\hline 10 & $1.84 \mathrm{~m}$ & 46.1 & $1,5,9,12$ & 9 \\
\hline 11 & - & 48.4 & $1,5,6,17$ & - \\
\hline 12 & $1.87 \mathrm{~m} \mathrm{(2H)}$ & 27.6 & 9 & 13 \\
\hline 13 & $2.43 \mathrm{~m}$ & 36.5 & - & 12,14 \\
\hline 14 & 4.00 brs & 75.3 & - & $9,13,14-\mathrm{OH}$ \\
\hline $15 \alpha$ & $2.50 \mathrm{~m}$ & 33.2 & $8-\mathrm{OH}$ & $15 \beta$ \\
\hline $15 \beta$ & $1.82 \mathrm{~m}$ & & & $15 \alpha$ \\
\hline 16 & $3.48 \mathrm{~m}$ & 81.8 & $15 \beta, 16-\mathrm{OMe}$ & $13,15 \alpha$ \\
\hline 17 & $3.28 \mathrm{~s}$ & 65.0 & $1,5,19 \mathrm{a}$ & $5^{*}$ \\
\hline $18 \mathrm{a}$ & $4.20 \mathrm{~d}(11.0)$ & 69.8 & $5,19 b$ & \\
\hline $18 \mathrm{~b}$ & $4.15 \mathrm{~d}(11.0)$ & & & \\
\hline $19 \mathrm{a}$ & $2.78 \mathrm{~m}$ & 52.6 & $5,17,18 \mathrm{a}, 18 \mathrm{~b}, 20 \mathrm{a}$ & $19 b$ \\
\hline $19 b$ & $2.53 \mathrm{~d}(8.9)$ & & & $19 \mathrm{a}$ \\
\hline $20 \mathrm{a}$ & $2.97 \mathrm{dq}(14.0,7.1)$ & 51.1 & 21 & $20 b, 21$ \\
\hline $20 b$ & $2.85 \mathrm{dq}(14.0,7.1)$ & & & $20 \mathrm{a}, 21$ \\
\hline 21 & $1.07 \mathrm{t}(7.1)$ & 14.1 & $20 a$ & $20 \mathrm{a}, 20 \mathrm{~b}$ \\
\hline $1^{\prime}$ & - & 114.7 & $3^{\prime}, 5^{\prime}, \mathrm{NH}$ & - \\
\hline $2^{\prime}$ & - & 141.7 & $4^{\prime}, 6^{\prime}$ & - \\
\hline $3^{\prime}$ & $8.70^{\prime} \mathrm{d}^{\prime}(8.3)$ & 120.7 & $5^{\prime}$ & $4^{\prime}$ \\
\hline $4^{\prime}$ & $7.55^{\prime} \mathrm{t}^{\prime}(7.6)$ & 134.9 & $6^{\prime}$ & $3^{\prime}, 5^{\prime}, 6^{\prime}$ \\
\hline $5^{\prime}$ & $7.11^{\prime} \mathrm{t}^{\prime}(8.0)$ & 122.6 & $3^{\prime}$ & $4^{\prime}, 6^{\prime}$ \\
\hline $6^{\prime}$ & $7.96^{\prime} \mathrm{d}^{\prime}(8.0)$ & 130.3 & $4^{\prime}$ & $4^{\prime}, 5^{\prime}$ \\
\hline $7^{\prime}$ & - & 168.1 & $3^{\prime}, 6^{\prime}, 18 \mathrm{a}, 18 \mathrm{~b}$ & - \\
\hline $1^{\prime \prime}$ & - & 170.2 & $2^{\prime \prime}, 3^{\prime \prime}, \mathrm{NH}$ & - \\
\hline $2^{\prime \prime}$ & $2.76 \mathrm{~m}(2 \mathrm{H})$ & 29.0 & $3^{\prime \prime}$ & - \\
\hline $3^{\prime \prime}$ & $2.76 \mathrm{~m}(2 \mathrm{H})$ & 32.8 & $2^{\prime \prime}$ & - \\
\hline $4^{\prime \prime}$ & - & 172.0 & $2^{\prime \prime}, 3^{\prime \prime}, 4^{\prime \prime}-\mathrm{OMe}$ & - \\
\hline 1-OMe & $3.26 \mathrm{~s}$ & 55.9 & 1 & - \\
\hline 6-OMe & $3.39 \mathrm{~s}$ & 58.4 & 6 & - \\
\hline 16-OMe & $3.36 \mathrm{~s}$ & 56.6 & - & - \\
\hline $4^{\prime \prime}-\mathrm{OMe}$ & $3.70 \mathrm{~s}$ & 51.8 & - & - \\
\hline $8-\mathrm{OH}$ & $3.53 \mathrm{~s}$ & - & & - \\
\hline $14-\mathrm{OH}$ & 4.33 brs & - & & 14 \\
\hline $\mathrm{NH}$ & $11.07 \mathrm{brs}$ & - & & - \\
\hline
\end{tabular}

Table 1. NMR spectral data of vulparine (1) $\left[500 \mathrm{MHz}\left({ }^{1} \mathrm{H}\right)\right.$, $125 \mathrm{MHz}\left({ }^{13} \mathrm{C}\right), \mathrm{CDCl}_{3}, \delta$ (ppm) $(J=\mathrm{Hz})]$.

$*{ }^{4} \mathrm{~J}_{\mathrm{H}, \mathrm{H}}$ correlations. detected between $\mathrm{H}-1$ and $\mathrm{H}-5$, and between $\mathrm{H}-1$ and $\mathrm{H}-10$. A detailed NMR study, including ${ }^{1} \mathrm{H}^{-}{ }^{1} \mathrm{H}$ COSY, HSQC and HMBC measurements, allowed (previously unpublished) ${ }^{1} \mathrm{H}$ chemical shift assignments for all the protons of 2 (Table 2). On the basis of the HMBC experiment, the ${ }^{13} \mathrm{C}$ NMR chemical shifts of 2 were reinvestigated, and some signal assignments were corrected. The long-range correlations of the carbon at $\delta_{\mathrm{C}}=50.4(\mathrm{C}-5)$ with $\mathrm{H}-18$, and of the carbon at $\delta_{\mathrm{C}}=43.1$ (C-9) with H-13, H-14 and H-15a, dictated amendment of the previous assignments of C-5 and
C-9. Similarly, the HMBC cross-peaks of the carbon at $\delta_{\mathrm{C}}=45.9(\mathrm{C}-10)$ with $\mathrm{H}-9$ and $\mathrm{H}-13$, and of the carbon at $\delta_{\mathrm{C}}=37.9(\mathrm{C}-13)$ with $\mathrm{H}-9, \mathrm{H}-14$ and $\mathrm{H}-15 \mathrm{a}$, showed that the published assignments of $\mathrm{C}-10$ and $\mathrm{C}-13$ must be reversed.

Compound 3 was found to be identical in all of its characteristics, including the ${ }^{1} \mathrm{H}$ and ${ }^{13} \mathrm{C}$ NMR spectral data, with finetiadine isolated earlier from $A$. finetianum [17]. Alkaloids $\mathbf{1 - 3}$ are structurally closely related to the highly potent nAChR ligand MLA, and appear worthy of pharmacological studies. Norditer- 
Table 2. ${ }^{1} \mathrm{H}$ NMR spectral data of compounds 2 and $\mathbf{6}$ $\left[500 \mathrm{MHz}, \mathrm{CDCl}_{3}, \delta(\mathrm{ppm}),(\mathrm{J}=\mathrm{Hz})\right]$.

\begin{tabular}{|c|c|c|}
\hline$\overline{\mathrm{H}}$ & 2 & 6 \\
\hline$\overline{1}$ & $3.03 \mathrm{~m}$ & $2.96 \mathrm{~m}$ \\
\hline $2 \mathrm{a}$ & $2.18 \mathrm{~m}(\alpha)$ & $2.12 \mathrm{~m}$ \\
\hline $2 b$ & $2.06 \mathrm{~m}(\beta)$ & $2.03 \mathrm{~m}$ \\
\hline $3 a$ & $1.85 \mathrm{~m}(\alpha)$ & $1.66 \mathrm{~m}$ \\
\hline $3 b$ & $1.55 \mathrm{~m}(\beta)$ & $1.47 \mathrm{~m}$ \\
\hline 5 & $1.74 \mathrm{~s}$ & $1.77 \mathrm{~s}$ \\
\hline 6 & $3.91 \mathrm{~s}$ & $3.83 \mathrm{brs}$ \\
\hline 9 & $3.08 \mathrm{dd}(6.8,5.0)$ & $3.13 \mathrm{~m}$ \\
\hline 10 & $1.97 \mathrm{~m}$ & $1.82 \mathrm{~m}$ \\
\hline $12 \mathrm{a}$ & $2.41 \mathrm{~d}(11.3)(\alpha)$ & $1.83 \mathrm{~m}(2 \mathrm{H})$ \\
\hline $12 b$ & $1.85 \mathrm{~m}(\beta)$ & \\
\hline 13 & $2.34 \mathrm{dd}(7.1,4.6)$ & $2.42 \mathrm{~m}$ \\
\hline 14 & $3.61 \mathrm{t}(4.6)$ & $3.99 \mathrm{brs}$ \\
\hline $15 \mathrm{a}$ & $2.61 \mathrm{dd}(15.3,8.9)(\alpha)$ & $2.49 \mathrm{dd}(15.3,7.8)$ \\
\hline $15 b$ & $1.69 \mathrm{dd}(15.3,7.0)(\beta)$ & $1.81 \mathrm{~m}$ \\
\hline 16 & $3.22 \mathrm{t}(7.6)$ & $3.46 \mathrm{~m}$ \\
\hline 17 & $2.98 \mathrm{~s}$ & $3.23 \mathrm{~s}$ \\
\hline $18 \mathrm{a}$ & $4.20 \mathrm{~d}(11.6)$ & $3.62 \mathrm{~d}(10.3)$ \\
\hline $18 b$ & $4.17 \mathrm{~d}(11.6)$ & $3.35 \mathrm{~d}(10.3)$ \\
\hline $19 a$ & $2.87 \mathrm{~d}(11.7)$ & $2.61 \mathrm{~d}$ \\
\hline $19 b$ & $2.80 \mathrm{~m}$ & $2.32 \mathrm{~d}$ \\
\hline $20 \mathrm{a}$ & $3.03 \mathrm{~m}$ & $2.94 \mathrm{~m}$ \\
\hline $20 \mathrm{~b}$ & $2.87 \mathrm{~m}$ & $2.82 \mathrm{~m}$ \\
\hline 21 & $1.07 \mathrm{t}(7.1)$ & $1.05 \mathrm{t}(7.0)$ \\
\hline $3^{\prime}$ & $8.69 \mathrm{~d}(8.5)$ & - \\
\hline $4^{\prime}$ & $7.55 \mathrm{dt}(8.0,1.5)$ & - \\
\hline $5^{\prime}$ & $7.10 \mathrm{dt}(7.6,0.7)$ & - \\
\hline $6^{\prime}$ & $7.96 \mathrm{dd}(8.0,1.5)$ & - \\
\hline $2^{\prime \prime}, 3^{\prime \prime}$ & $2.75 \mathrm{~m}(4 \mathrm{H})$ & - \\
\hline 1-OMe & $3.26 \mathrm{~s}$ & $3.26 \mathrm{~s}$ \\
\hline 6-OMe & $3.37 \mathrm{~s}$ & $3.44 \mathrm{~s}$ \\
\hline 14-OMe & $3.40 \mathrm{~s}$ & - \\
\hline 16-OMe & $3.34 \mathrm{~s}$ & $3.36 \mathrm{~s}$ \\
\hline $4^{\prime \prime}-\mathrm{OMe}$ & $3.70 \mathrm{~s}$ & - \\
\hline $8-\mathrm{OH}$ & 3.91 brs & $3.61 \mathrm{~s}$ \\
\hline $14-\mathrm{OH}$ & - & $4.31 \mathrm{brs}$ \\
\hline $\mathrm{NH}$ & $11.06 \mathrm{brs}$ & - \\
\hline
\end{tabular}

pene alkaloids substituted with 2-succinimidobenzoate groups (e.g. MLA) often occur in Aconitum and Delphinium species, but compounds in which the succinimido part is opened (such as $\mathbf{1 - 3}$ ) are rare [10].

The ${ }^{13} \mathrm{C}$ chemical shifts and physical data for $\mathbf{4}$ confirmed that this compound is identical with anthranoyllycoctonine (= inuline), previously detected in many species of the genera Aconitum, Delphinium, Consolida and Inula [10].

The NMR spectral data on compound $\mathbf{5}$ were very similar to those of lycoctonine. The only difference was the absence of the signals of the $N$-ethyl group $\left(\delta_{\mathrm{H}}=2.93 \mathrm{~m}, 2.79 \mathrm{dq}, 1.04 \mathrm{t} ; \delta_{\mathrm{C}}=51.1,14.1\right.$ in lycoctonine) [9] and the appearance of an $N$-methyl signal $\left(\delta_{\mathrm{H}}=2,62 \mathrm{~s} ; \delta_{\mathrm{C}}=44.4\right)$. The good agreement of the other ${ }^{1} \mathrm{H}$ and ${ }^{13} \mathrm{C}$ NMR data for 5 and lycoc-
Table 3. Cytotoxic activity of compounds $\mathbf{1}-\mathbf{4}$.

\begin{tabular}{llll}
\hline Compound & $\begin{array}{l}\text { Concentration } \\
(\mu \mathrm{g} / \mathrm{mL})\end{array}$ & \multicolumn{2}{c}{ Inhibition $(\%) \pm$ SEM } \\
& 10 & $<15$ & $<$ HeLa \\
\hline Vulparine (1) & 30 & $<15$ & $<15$ \\
& 10 & $<15$ & $<15$ \\
Septentriodine (2) & 30 & $34.50 \pm 3.72$ & $<15$ \\
& 10 & $19.28 \pm 4.24$ & $19.91 \pm 1.76$ \\
Finetiadine (3) & 30 & $39.48 \pm 3.42$ & $25.59 \pm 1.87$ \\
& 10 & $29.82 \pm 5.69$ & $<15$ \\
Anthranoyl & 30 & $20.70 \pm 3.02$ & $17.33 \pm 1.60$ \\
-lycoctonine (4) & 3 & $53.01 \pm 2.33$ & $42.55 \pm 2.92$ \\
Cisplatin & 30 & $86.90 \pm 1.24$ & $99.93 \pm 0.26$ \\
& & &
\end{tabular}

tonine proved the structure $N$-methyl- $N$-deethyllycoctonine for compound $\mathbf{5}$. Previously, only the mass spectrum of $N$-methyl- $N$-deethyllycoctonine had been reported [18].

Compound 6 was a trimethoxy-tetrahydroxysubstituted lycoctonine-type alkaloid, which, with the aid of 2D NMR measurements, was identified as delectinine. The previously reported spectral data [10] on delectinine (6) were supplemented with complete ${ }^{1} \mathrm{H}$ NMR assignments (Table 2), and with the correction of some of the ${ }^{13} \mathrm{C}$ NMR chemical shifts. Diagnostic long-range correlations between $\mathrm{C}-5 / \mathrm{H}-17$, C-9/H-10 and C-9/H-14, and ${ }^{1} \mathrm{H}-{ }^{1} \mathrm{H}$ COSY correlations between $\mathrm{H}-10 / \mathrm{H}-9, \mathrm{H}-13 / \mathrm{H}-12, \mathrm{H}-13 / \mathrm{H}-14$ and $\mathrm{H}-13 / \mathrm{H}-16$, were indicative of the need to correct the ${ }^{13} \mathrm{C}$ NMR chemical shifts of C-5 and C-9, and C-10 and $\mathrm{C}-13$.

The isolated norditerpene alkaloids $\mathbf{1}-\mathbf{4}$ were tested for their cytotoxic effect on MCF-7 and HeLa cells using MTT assay. The cell growth-inhibitory potencies of compounds $\mathbf{1 - 4}$ are shown in Table 3. Finetiadine (3) exhibited the highest cytotoxicity $(39.48 \pm 3.42 \%$ and $25.59 \pm 1.87 \%$ inhibition on MCF-7 and HeLa cells, respectively, at $30 \mu \mathrm{g} / \mathrm{mL}$ ). Septentriodine (2) and anthranoyllycoctonine (4) displayed marginal tumour cell inhibitory activity, while vulparine (1) was found to be inactive. In all cases MCF-7 cells were more sensitive than HeLa cells. The present results demonstrate that some anthranoyl-substituted norditerpene alkaloids possess weak cytotoxic potencies against human tumour cells depending on their substitutions pattern.

\section{Experimental Section}

General procedure

Optical rotations were determined in $\mathrm{CHCl}_{3}$ with a Perkin-Elmer 341 polarimeter. UV spectra were recorded on 
a Shimadzu UV-2101 PC spectrometer. NMR spectra were recorded in $\mathrm{CDCl}_{3}$ on a Bruker Avance DRX 500 spectrometer, at $500 \mathrm{MHz}\left({ }^{1} \mathrm{H}\right)$ and $125 \mathrm{MHz}\left({ }^{13} \mathrm{C}\right)$, with TMS as internal standard. 2D data were acquired and processed with standard Bruker software. HRMS measurement was performed on a VG ZAB SEQ hybrid mass spectrometer equipped with a Cs SIMS ion source. The resolution was 10000 . The sample was dissolved in methanol and this solution was measured with glycerol as matrix. The glycerol cluster peak at $\mathrm{m} / \mathrm{z}=645$ was used in peak matching experiments. Centrifugal TLC was performed with a Chromatotron (Model 8924, Harrison Research).

\section{Plant material}

Aconitum vulparia Rchb. was collected in the region of Nagyvázsony, Hungary, in September 2002, and was identified by András Mészáros, Balaton Uplands National Park, Veszprém, Hungary. A voucher specimen (No. 617) has been deposited in the Herbarium of the Department of Pharmacognosy, University of Szeged, Szeged, Hungary.

\section{Extraction and isolation}

Dried whole plants of $A$. vulparia $(250 \mathrm{~g})$ were crushed in a blender and then percolated with $\mathrm{MeOH}(12 \mathrm{~L})$. After evaporation, the crude extract was dissolved in $4 \%$ aq. $\mathrm{H}_{2} \mathrm{SO}_{4}(250 \mathrm{~mL})$ and extracted exhaustively with $\mathrm{CHCl}_{3}$, which yielded organic layer I and aqueous layer II. After adjustment of the $\mathrm{pH}$ to 12 , aqueous layer II was extracted with $\mathrm{CHCl}_{3}$, affording organic layer III. This fraction (III) was evaporated under reduced pressure, and fractionated by VLC (VLC I) on $\mathrm{Al}_{2} \mathrm{O}_{3}$, using a gradient system of $n$-hexane/EtOAc/MeOH $(50: 50: 1,50: 50: 1.5$, $50: 50: 2,50: 50: 3,50: 50: 4,50: 50: 5,50: 50: 10)$. Fractions obtained with $n$-hexane/EtOAc/MeOH $50: 50: 3$, $50: 50: 4$ and $50: 50: 5$ were further fractionated by VLC on $\mathrm{Al}_{2} \mathrm{O}_{3}$, using a gradient system of $n$-hexane/ $\mathrm{CHCl}_{3}$ $(7: 3,6: 4,1: 1,4: 6,3: 7,2: 8,1: 9)$. Compound 2 was obtained in pure form from the fractions eluted with $n$-hexane/ $\mathrm{CHCl}_{3} \quad 6: 4$. The fractions eluted with $n$ hexane/ $\mathrm{CHCl}_{3} 1: 1$ were further purified by gel chromatography, using $\mathrm{MeOH} / \mathrm{CHCl}_{3} 1: 1$ as solvent, yielding compound 1. Organic layer I was extracted with $2 \%$ aqueous $\mathrm{H}_{2} \mathrm{SO}_{4}$, which afforded aqueous layer IV. Aqueous layer IV was then rendered alkaline with $5 \%$ aqueous $\mathrm{NaOH}$ solution, and extracted with $\mathrm{CHCl}_{3}$ (organic layer V). Phase V was evaporated in vacuo, and separated by VLC (VLC II), using a gradient system of $n$-hexane/EtOAc/MeOH $\left(\mathrm{Al}_{2} \mathrm{O}_{3} ; 50: 50: 0.5,50: 50: 1,50: 50: 1.5,50: 50: 2\right.$, $50: 50: 3,50: 50: 4,50: 50: 5,50: 50: 10,1: 1: 1)$. The fractions obtained by eluting with $n$-hexane/EtOAc/MeOH $50: 50: 0.5$ were further purified by gel chromatography (solvent: $\left.\mathrm{MeOH} / \mathrm{CHCl}_{3} 1: 1\right)$ and preparative $\mathrm{TLC}\left(\mathrm{SiO}_{2}\right.$, petroleum ether/diethyl ether/MeOH $50: 50: 7$ ), affording compound 4. The fractions eluted from VLC II with $n$ hexane/EtOAc/MeOH 50:50:2 and 50:50:3 were further purified by centrifugal TLC $\left(\mathrm{SiO}_{2}\right.$, gradient elution with cyclohexane/EtOAc/EtOH $1: 0: 0,9: 1: 0,8: 2: 1,6: 3: 1,0: 1: 1$, $0: 0: 1)$. The fractions derived from centrifugal TLC with $n$-hexane/EtOAc/MeOH $8: 2: 1$ were subjected to preparative TLC $\left(\mathrm{SiO}_{2}\right.$, toluene/acetone/EtOH/NH $\left.30: 40: 12: 3\right)$, yielding compound 3 . The fractions eluted from VLC II with $n$-hexane/EtOAc/MeOH $50: 50: 3$ and 50:50:4 were further fractionated by column chromatography on $\mathrm{SiO}_{2}$ with mixtures of cyclohexane/ $/ \mathrm{CHCl}_{3} / \mathrm{MeOH}$. The diterpene alkaloid-containing fractions from this chromatography were subjected to RP-VLC $\left(\mathrm{RP}-\mathrm{SiO}_{2}, \mathrm{MeOH} / \mathrm{H}_{2} \mathrm{O}\right.$ $1: 1,55: 45,60: 40,65: 35,70: 30,80: 20,90: 10)$. The final purification was performed by preparative TLC $\left(\mathrm{SiO}_{2}\right.$, toluene/acetone/EtOH/ $\mathrm{NH}_{3}$ 70:50:35:6), affording compound 5. The fractions eluted from VLC II with $n$ hexane/EtOAc/MeOH $50: 50: 10$ were subjected to preparative TLC $\left(\mathrm{SiO}_{2}\right.$, toluene/acetone/EtOH/NH $\left.30: 50: 35: 6\right)$ and gel chromatography $\left(\mathrm{CHCl}_{3} / \mathrm{MeOH} 1: 1\right)$, yielding compound 6.

Vulparine (1): amorphous solid; $[\alpha]_{\mathrm{D}}^{27}=+47(c=0.1$, $\left.\mathrm{CHCl}_{3}\right)$. - UV (MeOH): $\lambda_{\max }(\log \varepsilon)=223$ (3.04), $227 \mathrm{sh}$ (3.01), 252 (2.75), $260 \mathrm{sh}(2.65), 311(2.32) \mathrm{nm} .-{ }^{1} \mathrm{H}$ and ${ }^{13} \mathrm{C}$ NMR data, see Table 1. - HRMS: $\mathrm{m} / \mathrm{z}(\%)=687.3437$ $[\mathrm{M}+\mathrm{H}]^{+}$(calcd. 687.3493 for $\mathrm{C}_{36} \mathrm{H}_{51} \mathrm{~N}_{2} \mathrm{O}_{11}$ ).

Septentriodine (2): amorphous solid; $[\alpha]_{\mathrm{D}}^{27}=+37$ $\left(c=0.05, \mathrm{CHCl}_{3}\right) .-\mathrm{UV}(\mathrm{MeOH}): \lambda_{\max }(\log \varepsilon)=222$ (2.99), 227 sh (2.97), 252 (2.71), 260 sh (2.61), 310 (2.28) nm. $-{ }^{1} \mathrm{H}$ NMR data, see Table 2. $-{ }^{13} \mathrm{C}$ NMR $\left(\mathrm{CDCl}_{3}\right): \delta=83.8,83.6(\mathrm{C}-1, \mathrm{C}-14), 25.8(\mathrm{C}-2), 32.2$ (C-3), 37.4 (C-4), 50.4 (C-5), 90.8 (C-6), 88.3 (C-7), 77.5 (C-8), 43.1 (C-9), 45.9 (C-10), 48.9 (C-11), 28.5 (C-12), 37.9 (C-13), 33.6 (C-15), 82.4 (C-16), 64.2 (C-17), 69.7 (C-18), 52.4 (C-19), 50.7 (C-20), 13.8 (C-21), $114.5\left(\mathrm{C}-1^{\prime}\right), 141.5\left(\mathrm{C}-2^{\prime}\right), 120.5\left(\mathrm{C}-3^{\prime}\right), 134.6\left(\mathrm{C}-4^{\prime}\right)$, $122.4\left(\mathrm{C}-5^{\prime}\right), 130.1\left(\mathrm{C}-6^{\prime}\right), 167.8\left(\mathrm{C}-7^{\prime}\right), 170.0\left(\mathrm{C}-1^{\prime \prime}\right)$, $\left.28.8\left(\mathrm{C}-2^{\prime \prime}\right), 32.5{\mathrm{C}-3^{\prime \prime}}^{\prime}\right), 172.7\left(\mathrm{C}-4^{\prime \prime}\right), 55.5$ (1-OMe), 57.9 (6-OMe), 57.6 (14-OMe), 56.0 (16-OMe), 51.6 (4"-OMe).

Finetiadine (3): amorphous solid; $[\alpha]_{\mathrm{D}}^{27}=+27(c=0.05$, $\left.\mathrm{CHCl}_{3}\right)$. - UV (MeOH): $\lambda_{\max }(\log \varepsilon)=222$ (3.06), $228 \mathrm{sh}$ (3.02), 253 (2.77), 260 sh (2.68), 311 (2.36) nm. $-{ }^{1} \mathrm{H}$ and ${ }^{13} \mathrm{C}$ NMR data identical with those reported by $\mathrm{Wu}$ et al. [17].

Anthranoyllycoctonine (4): amorphous solid; $[\alpha]_{\mathrm{D}}^{27}=+80$ $\left(c=0.025, \mathrm{CHCl}_{3}\right) .-\mathrm{UV}(\mathrm{MeOH}): \lambda_{\max }(\log \varepsilon)=220$ (3.08), 248 (2.57), $340(2.39) \mathrm{nm} .-{ }^{1} \mathrm{H}$ and ${ }^{13} \mathrm{C}$ NMR data identical with those published by Hardick et al. [5].

$N$-Deethyl-N-methyllycoctonine (5): amorphous solid; ${ }^{1} \mathrm{H} \mathrm{NMR}\left(\mathrm{CDCl}_{3}\right): \delta=2.93(1 \mathrm{H}, \mathrm{dd}, J=10.0,7.3 \mathrm{~Hz}, \mathrm{H}-1)$, $3.85(1 \mathrm{H}, \mathrm{s}, \mathrm{H}-6), 3.07(1 \mathrm{H}, \mathrm{t}, J=5.7 \mathrm{~Hz}, \mathrm{H}-9), 2.81(1 \mathrm{H}$, 
$\mathrm{d}, J=1.6, \mathrm{H}-17), 2.62(1 \mathrm{H}, \mathrm{d}, J=9.1 \mathrm{~Hz}, \mathrm{H}-18 \mathrm{a}), 3.45$, $3.42,3.34,3.27\left(4 \times 3 \mathrm{H}, 4 \times \mathrm{s}, 4 \times \mathrm{OCH}_{3}\right), 2.62(3 \mathrm{H}, \mathrm{s}, \mathrm{N}$ $\left.\mathrm{CH}_{3}\right) .-{ }^{13} \mathrm{C} \mathrm{NMR}\left(\mathrm{CDCl}_{3}\right): \delta=84.7(\mathrm{C}-1), 26.1(\mathrm{C}-2), 29.7$ (C-3), 49.5 (C-5), 90.5 (C-6), 77.9 (C-8), 43.3 (C-9), 46.2 (C-10), 28.8 (C-12), 38.1 (C-13), 84.0 (C-14), 33.7 (C-15), 82.6 (C-16), 66.1 (C-17), 55.5 (C-18), 67.9 (C-19), 56.2, 58.0, 57.8, $56.3\left(4 \times \mathrm{OCH}_{3}\right), 44.4\left(\mathrm{~N}-\mathrm{CH}_{3}\right) .-{ }^{13} \mathrm{C} \mathrm{NMR}$ signals of C-4, C-7 and C-11 were not observed.

Delectinine (6): amorphous solid; $[\alpha]_{\mathrm{D}}^{27}=+31(c=0.05$, $\left.\mathrm{CHCl}_{3}\right)$. - UV (MeOH): $\lambda_{\max }(\log \varepsilon)=203$ (2.95), $218 \mathrm{sh}$ (2.78), 280 (2.06) nm. $-{ }^{1} \mathrm{H}$ NMR data, see Table 2. ${ }^{13} \mathrm{C} \mathrm{NMR}\left(\mathrm{CDCl}_{3}\right): \delta=85.2(\mathrm{C}-1), 25.4(\mathrm{C}-2), 31.7(\mathrm{C}-3)$, 38.9 (C-4), 49.6 (C-5), 90.2 (C-6), 89.1 (C-7), 76.3 (C-8), 45.1 (C-9), 46.1 (C-10), 48.2 (C-11), 27.5 (C-12), 36.4 (C-13), 75.3 (C-14), 33.1 (C-15), 81.8 (C-16), 65.4 (C-17), 67.8 (C-18), 52.7 (C-19), 51.2 (C-20), 14.3 (C-21), 56.0 (1-OMe), 58.1 (6-OMe), 56.5 (16-OMe).

\section{Bioassay}

Cytotoxic effects were measured in vitro on HeLa (cervix adenocarcinoma) and on breast adenocarcinoma (MCF-7) cell lines, using the MTT [3-(4,5-dimethylthiazol-2-yl)-2,5diphenyltetrazolium bromide] colorimetric assay. The cyto- toxicity tests were carried out in 96-well microtitre plates, using 5000 cells per well in all cases, which were allowed to adhere overnight before the drugs were introduced. The original medium was then removed, $200 \mu \mathrm{L}$ culture medium containing the compounds of interest was added and the cells were incubated for $72 \mathrm{~h}$. The tested compounds were dissolved in DMSO. The final concentration of DMSO never exceeded $0.3 \%$, and therefore had no essential effect on the cell growth. Next the living cells were assayed: aliquots $(20 \mu \mathrm{L}$ at $5 \mathrm{mg} / \mathrm{mL}$ ) of the MTT stock solution were pipetted into each well and reduced by viable cells to an insoluble formazan product during a further $4 \mathrm{~h}$. After this contact period, the medium was removed and the formazan crystals were dissolved in $100 \mu \mathrm{L}$ DMSO by gentle shaking for $60 \mathrm{~min}$. Finally, the absorbance was measured at $545 \mathrm{~nm}$ with a microplate reader [19]. In this way the cell growth or drug toxicity was determined. All in vitro experiments were carried out on two microplates with at least 5 parallel wells.

\section{Acknowledgements}

This work was supported by the Hungarian Research Fund (OTKA) through grant T038390 and by the Council for Health Research through grant ETT-382/2003.
[1] A. M. Bello-Ramirez, A. A. Nava-Ocampo, Fundam. Clin. Pharmacol. 2004, 18, 699-704.

[2] J. Friese, J. Gleitz, U.T. Gutser, J.F. Heubach, T. Matthiesen, B. Wilffert, N. Selve, Eur. J. Pharmacol. 1997, 337, 165- 174 .

[3] F. Shaheen, M. Ahmad, M. T. Khan, S. Jalil, A. Ejaz, M. N. Sultankhodjaev, M. Arfan, M.I. Choudhary, A. Rahman, Phytochemistry 2005, 66, $935-940$.

[4] S. R. Breining, Curr. Top. Med. Chem. 2004, 4, 609629.

[5] D. J. Hardick, I. S. Blagbrough, G. Cooper, B. V. Potter, T. Critchley, S. Wonnacott, J. Med. Chem. 1996, 39, $4860-4866$.

[6] A. Gonzalez-Coloma, M. Reina, A. Medinaveitia, A. Guadano, O. Santana, R. Martinez-Diaz, L. RuizMesia, A. Alva, M. Grandez, R. Diaz, J. A. Gavin, G. De la, Fuente, J. Chem. Ecol. 2004, 30, 1393 - 1408.

[7] C. de Ines, M. Reina, J. A. Gavin, A. Gonzalez-Coloma, Z. Naturforsch. 2006, 61c, $11-18$.

[8] A. Chodoeva, J. J. Bosc, J. Guillon, A. Decendit, M. Petraud, C. Absalon, C. Vitry, C. Jarry, J. Robert, Bioorg. Med. Chem. 2005, 13, 6493-6501.
[9] D. Csupor, P. Forgo, I. Mathe, J. Hohmann, Helv. Chim. Acta 2004, 87, 2125-2130.

[10] S. W. Pelletier, N. V. Mody, B. S. Joshi, L. C. Schramm, in Alkaloids: Chemical and Biological Perspectives, Vol. 2 (Ed.: S. W. Pelletier), Wiley, New York, 1984, pp. $205-462$.

[11] N. Batbayar, S. Enkhzaya, J. Tunsag, D. Batsuren, D. S. Rycroft, S. Sproll, F. Bracher, Phytochemistry 2003, 62, 543-550.

[12] Y. Chen, A. Katz, J. Nat. Prod. 1999, 62, $798-799$.

[13] S. W. Pelletier, R. S. Sawhney, A. J. Aasen, Heterocycles 1979, 12, 377-381.

[14] M. Shamma, P. Chinnasamy, G. A. Miana, A. Khan, M. Bashir, M. Salazar, P. Patil, J. L. Beal, J. Nat. Prod. 1979, 42, 615-623.

[15] Y. Dequan, B. C. Das, Planta Med. 1983, 49, 85-89.

[16] H. M. Sayed, H. K. Desai, S. A. Ross, S. W. Pelletier, A. J. Aasen, J. Nat. Prod. 1992, 55, $1595-1606$.

[17] G. Wu, S. H. Jiang, D. Y. Zhu, Phytochemistry 1996, $42,1253-1255$.

[18] M. S. Yunusov, Y. V. Rashkes, V. A. Tel'nov, S. Y. Yunusov, Khim. Prir. Soedin. 1969, 5, 515-519

[19] T. Mosmann, Immunol. Methods 1983, 65, 55-63. 